\title{
PEMBANGUNAN BERKELANJUTAN \\ MENJADI DASAR TERINTEGRASI DALAM PEMBANGUNAN \\ SUATU WILAYAH BERDASARKAN UNDANG-UNDANG NO. 32 \\ TAHUN 2009 TENTANG PERLINDUNGAN DAN \\ PENGELOLAAN LINGKUNGAN HIDUP
}

Oleh : Farahwati

Dosen Fakultas Hukum Universitas 17 Agustus 1945 Samarinda

\begin{abstract}
The environment on earth as regulated in Law No. 32 of 2009 concerning Environmental Protection and Management, that environmental management consists of the natural environment in accordance with the understanding of ecosystem life and social environment that is illustrated by the existence of human groups both in society and in families and refers to the understanding of humanity (humanism), so that includes understanding about between nations, interregion and the built environment (originally thought to be man-made; man-made environment).

Development needs to pay attention to environmental conditions that exist from the physical side (soil, water, air), biotics (flora, fauna), and culture (culture, interactions between people). Environmental quality conditions will tend to continue to decline if not balanced with the concept of sustainable development planning in an effort to preserve the existing environmental functions.

The implementation of environmentally sound development and the controlled use of natural resources wisely is the main objective of environmental management. Sustainable development is very closely related to environmental management programs and policies.

The nature of environmental law enforcement in sustainable development covers all environmental law systems with the aim of protecting and properly managing the environment and is an activity to implement and apply just environmental laws and take legal action against any violations or deviations of law committed by legal subjects either through judicial procedures or through non-judicial procedures. Legal norms are the most dominant rules that are enforced with power and for their violations subject to certain sanctions that have been established by the State.
\end{abstract}

Keyword : Sustainable development, Enforcement of environmental laws. 


\begin{abstract}
ABSTRAK
Lingkungan hidup di bumi sebagaimana telah diatur di dalam Undang-undang No. 32 Tahun 2009 tentang Perlindungan dan Pengelolaan Lingkungan Hidup, bahwa pengelolaan lingkungan hidup terdiri atas lingkungan hidup alam yang sesuai dengan pengertian kehidupan ekosistem dan lingkungan hidup sosial yang digambarkan dengan adanya kelompok manusia baik dalam masyarakat maupun dalam keluarga serta mengacu pada paham tentang kemanusiaan (humanisme), sehingga mencakup paham tentang antar bangsa, interregion dan lingkungan hidup binaan.

Pembangunan perlu memperhatikan kondisi lingkungan yang ada dari sisi fisik (tanah, air, udara), biotik (flora, fauna), dan kultur (budaya, interaksi antar manusia). Kondisi kualitas lingkungan akan cenderung menurun terus jika tidak diimbangi dengan konsep perencanaan pembangunan yang berkelanjutan dalam upaya melestarikan fungsi lingkungan hidup.

Terlaksananya pembangunan berwawasan lingkungan dan terkendalinya pemanfaatan sumber daya alam yang secara bijaksana merupakan tujuan utama pengelolaan lingkungan hidup. Pembangunan yang berkelanjutan sangat berkaitan erat dengan program serta kebijakan pengelolaan lingkungan hidup.

Hakekat penegakkan hukum lingkungan pada pembangunan berkelanjutan mencakup seluruh sistem hukum lingkungan dengan tujuan untuk melindungi dan mengelola lingkungan dengan benar dan merupakan suatu kegiatan untuk melaksanakan dan menerapkan hukum lingkungan yang berkeadilan serta melakukan tindakan hukum terhadap setiap pelanggaran atau penyimpangan hukum yang dilakukan oleh subjek hukum baik melalui prosedur peradilan ataupun melalui prosedur di luar peradilan. Norma hukum merupakan aturan yang paling dominan yang ditegakkan dengan kekuasaan dan atas pelanggarannnya di kenai sanksisanksi tertentu yang telah ditetapkan oleh Negara.
\end{abstract}

Kata Kunci :Pembangunan berkelanjutan, Penegakkan hukum lingkungan 


\section{PENDAHULUAN}

\section{A. Latar Belakang}

Lingkungan hidup di bumi sebagaimana di dalam Undang-Undang No. 32 Tahun 2009 tentang Perlindungan dan Pengelolaan Lingkungan Hidup, bahwa pengelolaan lingkungan hidup terdiri atas lingkungan hidup alam yang sesuai dengan pengertian kehidupan ekosistem, lingkungan hidup sosial yang digambarkan dengan adanya kelompok manusia baik dalam masyarakat maupun dalam keluarga serta mengacu pada paham tentang kemanusiaan (humanisme), sehingga mencakup paham tentang antar bangsa, interregion maupun international dan lingkungan hidup binaan (semula dianggap buatan manusia; man-made environment). Lingkungan binaan makhluk hidup dimungkinkan karena adanya komponen daya dari berbagai makhluk hidup untuk bisa survive, mempertahankan keberadaan (eksistensi) diri dan keturunannya.

Pembangunan yang telah dilaksanakan oleh pemerintah telah menunjukkan hasil di berbagai bidang kehidupan masyarakat yang meliputi bidang sosial, budaya, ekonomi, ilmu pengetahuan dan teknologi, kehidupan beragama, politik, hukum pertahanan dan keamanan, pembangunan wilayah dan tata ruang serta pengelolaan lingkungan hidup. Keberhasilan suatu pembangunan harus juga ditunjang oleh berbagai aspek seperti kondisi politik yang stabil, jaminan keamanan, modal yang cukup, sumber daya manusia yang berkualitas, ilmu pengetahuan serta ketersediaan sumber daya alam. Pendayagunaan sumber daya alam baik hayati maupun non hayati sangat mempengaruhi kondisi lingkungan bahkan dapat merombak sistem kehidupan yang sudah berimbang antara kehidupan itu sendiri dengan lingkungannya. ${ }^{1}$ Sehingga manusia di dalam memanfaatkan sumber daya alam harus memperhatikan tujuannya dan pengaruh (dampak) yang akan ditimbulkan akibat pemakaian. ${ }^{2}$

Telah banyak kemajuan yang dicapai, akan tetapi masih banyak tantangan atau masalah yang belum sepenuhnya terselesaikan. Salah satu tantangan atau masalah yang sepenuhnya belum terselesaikan seperti masalah pencemaran dan kerusakan lingkungan sebagai efek samping dari berjalannya proses pembangunan. Pengelolaan sumber daya alam tersebut, masih belum berkelanjutan dan masih mengabaikan kelestarian fungsi lingkungan hidup sehingga daya dukung lingkungan menurun dan ketersediaan sumber daya alam menipis. Menurunnya daya dukung dan ketersediaan sumber daya alam juga terjadi karena kemampuan ilmu

\footnotetext{
${ }^{1}$ Joko Subagyo, 2005, Hukum Lingkungan Masalah dan Penanggulangannya, Rineka Cipta, hal 1.

${ }^{2}$ Ibid.
} 
pengetahuan tentang lingkungan hidup dan teknologi yang rendah sehingga tidak mampu mengimbangi laju pertumbuhan penduduk. ${ }^{3}$

Berbagai kasus pencemaran dan kerusakan lingkungan hidup yang menonjol sebagai efek samping dari proses pembangunan adalah kerusakan sumber daya alam dan meningkatnya tuntutan atas lahan. Untuk mengatasi masalah yang ditimbulkan akibat kegiatan pada lingkungan hidup maka pemerintah selalu memberikan batasan-batasan dalam bentuk suatu peraturan atau kebijaksanaan. Di dalam pengelolaan lingkungan hidup, berasaskan pada pelestarian kemampuan lingkungan hidup agar hubungan manusia dengan lingkungannya selalu berada pada kondisi optimum dalam arti manusia dapat memanfaatkan sumber daya dengan dilakukan secara terkendali dan lingkungannya mampu menciptakana sumbernya untuk dibudidayakan. ${ }^{4}$

Menyadari potensi dampak negatif yang ditimbulkan sebagai konsekuensi dari pembangunan terus dikembangkan upaya pengendalian dampak secara dini. Analisis mengenai dampak lingkungan adalah merupakan salah satu perangkat preemtif dan preventif pengelolaan lingkungan hidup yang terus diperkuat melalui peningkatan akuntabilitas dalam pelaksanaan penyusunan amdal dengan mempersyaratkan lisensi bagi penilai amdal dan diterapkannya sertifikasi bagi penyusun dokumen amdal serta dengan memperjelas sanksi hukum bagi pelanggar di bidang amdal. ${ }^{5}$ Amdal menjadi salah satu persyaratan utama dalam memperoleh izin lingkungan yang mutlak dimiliki sebelum diperoleh izin usaha dan atau kegiatan yang direncnakan pada lingkungan hidup.

Salah satu fungsi Negara dalam sistem Negara modern adalah mengatur hubungan-hubungan manusia yang terjadi dalam masyarakat, memberikan pembatasan atau keleluasaan serta memenuhi kebutuhan masyarakatnya, karena itu peraturan perundang-undangan dibentuk oleh Negara dan digunakan untuk mengatur tata tertib masyarakat (Mac Iver: Negara Modern, 1980, hal 12-14). ${ }^{6}$ Indonesia merupakan negara modern persyaratan sebagai sebuah Negara sudah terpenuhi sejak Kemerdekaan Republik Indonesia, sebagai Negara demokrasi jelas tercantum dalam UUD 1945. Dikatakan dalam suatu Negara modern, Negara menghukum siapa saja yang melanggar peraturan, Negara menciptakan sistem hak dan kewajiban yang sangat luas dan menjamin hak-hak tersebut dengan memaksakan dilakukannya kewajiban-kewajiban. Undang-Undang tentang perlindungan dan pengelolaan lingkungan hidup, mengatur perilaku manusia dalam memenfaatkan sumber daya alam, harus

\footnotetext{
${ }^{3}$ A'an Efendi, Op Cit., hal 2.

${ }^{4}$ Ibid.

5 Ibid, butir 4

${ }^{6}$ Ibid, hal 39.
} 
memperhatikan tujuannya dan dampak yang akan ditimbulkan akibat penggunaan lingkungan hidup, dengan latar belakang yang disadari bahwa lingkungan hidup memiliki kedudukan serta peranan penting bagi kehidupan manusia di bumi ini.

\section{B. Pembatasan Masalah}

Pembatasan masalah dalam penulisan ilmiah ini mengenai kegiatan dan atau pembangunan yang berkelanjutan sebagai dasar dan terintegrasi dalam pembangunan suatu wilayah berdasarkan Undangundang No. 32 Tahun 2009 tentang Perlindungan dan Pengelolaan Lingkungan Hidup, dan bagaimana ketentuan Penegakkan hukum lingkungan terkait dengan kegiatan Pembangunan, sehingga pemanfaatan lingkungan hidup yang terkait dengan pembangunan suatu wilayah dapat bermanfaat bagi rakyat dan menunjang pembangunan yang berkelajutan.

\section{Tujuan Penulisan Ilmiah}

Melakukan kajian atas kegiatan/pembangunan berkelanjutan sebagai dasar dan terintegrasi dalam pembangunan suatu wilayah berdasarkan Undang-undang No. 32 Tahun 2009 Tentang Perlindungan dan Pengelolaan Lingkungan Hidup. dan kajian tentang ketentuan Penegakan hukum lingkungan terkait dengan kegiatan pembangunan yang dilakukan pada lingkungan hidup.

\section{KERANGKA DASAR TEORI}

\section{A. Peraturan Perundang-undangan Lingkungan Hidup}

Problematika pembangunan dan lingkungan hidup bukanlah persoalan yang hanya dialami oleh Pemerintah Indonesia saja. Akan tetapi problematika pembangunan dan lingkungan hidup sudah merupakan persoalan global yang menjadi perhatian pada setiap Negara-negara di dunia. Problematika pembangunan dan lingkungan telah dibahas di dalam konferensi Perserikatan Bangsa-Bangsa (PBB) tentang lingkungan hidup atau United Nations Conference on The Human Environment pada tanggal 5-16 Juni 1972 di Stockholm, Swedia. ${ }^{7}$ Yang membahas tentang permasalahan lingkungan hidup dan jalan keluarnya untuk dapat menyelesaikannya, yang mana pembangunan dapat terlaksana dengan memperhitungkan daya dukung lingkungan (ecodevelopment). Di Rio de Janerio, Brazil tanggal 2-14 Juni 1992 dari penyelenggaraan United Nations Conference on Environmental and development di Rio Janerio ini telah meletakkan fondasi dasar yang pertautan antara segmen lingkungan

\footnotetext{
${ }^{7}$ A'an Efendi, Op Cit., hal 4.
} 
dan pembangunan dalam spektrum besar yang disebut 'pembangunan berkelanjutan'. ${ }^{8}$ Pembangunan berkelanjutan adalah keseimbangan antara pembangunan ekonomi, sosial dan lingkungan hidup, pembangunan yang dapat memenuhi kebutuhan pada generasi sekarang tanpa mengurangi kesempatan bagi generasi yang akan datang untuk memenuhi kebutuhannya.

Pada pasal 1 angka 3 Undang-undang No. 32 Tahun 2009 tentang perlindungan dan pengelolaan lingkungan hidup, bahwa yang dimaksud dengan pembangunan berkelanjutan adalah upaya sadar dan terencana yang memadukan aspek lingkungan hidup, sosial dan ekonomi kedalam strategi pembangunan untuk menjamin keutuhan lingkungan hidup serta keselamatan, kemampuan, kesejahteraan, dan mutu hidup generasi masa kini dan generasi masa depan. Menurut Emil Salim, terdapat tiga pokok dalam pengertian pembangunan berkelanjutan yaitu : ${ }^{9}$

1. Konsep kebutuhan. Pengkal tolak pembangunan berkelanjutan haruslah untuk mencapai pemenuhan kebutuhan pokok semua manusia.

2. Menyangkut konsep pengembangan lingkungan yang mampu mendukung proses pembangunan agar bisa berlanjut untuk jangka panjang.

3. Mengalirnya pembangunan dari generasi kini ke lain generasi masa depan tanpa kekurangan resource dan dengan kemampuan manusia memenuhi kebutuhannya.

\section{B. Analisis Mengenai Dampak Lingkungan}

Pencemaran lingkungan yang berdampak berubahnya tatanan lingkungan karena kegiatan manusia atau oleh proses alam berakibat lingkungan kurang atau tidak berfungsi lagi sesuai dengan peruntukannya. Pencemaran berakibatkan kualitas lingkungan menurun, akan menjadi fatal apabila tidak dapat dimanfaatkan sebagaimana fungsi sesungguhnya. Dengan menyadari bahwa setiap kegiatan pada dasarnya menimbulkan dampak terhadap lingkungan hidup maka perlu dengan perkiraan pada perencanaa awal, sehingga dengan cara demikian dapat dipersiapkan langkah pencegahan maupun penanggulangan dampak negatifnya dan mengupayakan dalam bentuk pengembangan dampak positif dari kegiatan tersebut. ${ }^{10}$

Saat ini Negara kita masih juga berlangsung adanya perusakan dan pencemaran lingkungan hidup yang massif seperti adanya pembangunan

\footnotetext{
${ }^{8}$ ibid.

${ }^{9}$ Ibid.

${ }^{10}$ Joko Subagyo, Op Cit hal. 27.
} 
yang tanpa izin, pembalakan liar, penambangan, pembukaan lahan dengan membakar, pembuangan limbah pabrik dan kegiatan destruktif lainnya. Oleh karena itu, sebagai perhatian pemerintah untuk dapat menanggulangi kerusakan dan/atau pencemaran yang diakibatkan oleh kegiatan manusia maka dibentuklah suatu peraturan perundang-undangan yang mengatur tentang lingkungan hidup yang baru sebagai dasar pelaksanaan pembangunan yang berwawasan lingkungan hidup yaitu Undang-Undang No. 32 Tahun 2009 tentang 'perlindungan dan pengelolaan lingkungan hidup' yang memacu pelaksanaan pembangunan yang berwawasan lingkungan hidup dan menjadi pertimbangan pokok dalam pelaksanaan kegiatan dan /atau usaha ke dalam lingkungan hidup. Dan setiap kerusakan lingkungan hidup yang diakibatkan oleh perbuatan/kegiatan manusia dapat dikembalikan kepada manusianya itu sendiri sebagai sobjek hukum pertanggungjawabannya, karena ada suatu pelanggaran hukum yang dilakukannya.

Analisis mengenai dampak lingkungan hidup yang merupakan kajian mengenai dampak penting suatu usaha dan/atau kegiatan yang direncanakan pada lingkungan hidup yang diperlukan bagi proses pengambilan keputusan tentang penyelenggaraan usaha dan/atau kegiatan tersebut, sangat diperlukan untuk menjaga keseimbangan dalam suatu ekosistem, disamping untuk melakukan rangkaian upaya pengelolaan sehingga secepatnya dilakukan pembaharuan apabila terjadi penurunan kualitas lingkungan hidup karena terjadinya gangguan keseimbangan pada ekosistem. ${ }^{11}$

Undang - undang No. 32 Tahun 2009 tentang 'Perlindungan dan Pengelolaan Lingkungan Hidup' sebagaimana disebutkan pada :

Pasal 22.

(1) Setiap usaha dan/atau kegiatan yang berdampak penting terhadap lingkungan hidup wajib memiliki amdal.

(2) Dampak penting di tentukan berdasarkan kriteria :

a. Besarnya jumlah penduduk yang akan terkena dampak rencana usaha dan/atau kegiatan.

b. Luas wilayah penyebaran dampak.

c. Intensitas berlangsung dan lamanya dampak.

d. Banyaknya komponen lingkungan lain yang akan terkena dampak.

e. Sifat komulatif dampak.

f. Berbalik dan /atau tidak berbaliknya dampak.

g. Kriteria lain perkembangan ilmu teknologi sesuai dengan pengetahuan dan teknologi.

${ }^{11}$ Ibid, hal 94 
Pasal 29.

(1) Dokumen amdal dinilai oleh komisi Penilai amdal yang dibentuk oleh Menteri, Gubernur atau Bupati/Walikota sesuai dengan kewenangannya.

(2) Komisi penilai amdal wajib memiliki lisensi dari Menteri, Gubernur atau Bupati/Walikota sesuai dengan kewenangannya.

(3) Persyaratan dan tata cara lisensi diatur dengan Peraturan Menteri.

Pasal 31.

- Berdasarkan hasil penilaian Komisi Penilai Amdal, Menteri, Gubernur, Bupati/Walikota menetapkan keputusan kelayakan atau ketidaklayakan lingkungan hidup sesuai dengan kewenangannya.

Tujuan utama dari pembuatan amdal yang telah menjadi ketentuan yang bersifat global (salah satu asas dalam Deklarasi Rio De Jeneiro 1992) ialah mencegah dampak yang negatif terhadap lingkungan yang mencemaskan secara nasional dan internasional. Dampak itu belum tentu terjadi tetapi diperkirakan dapat terjadi. Dampak yang positif dapat ditingkatkan dan dikembangkan. ${ }^{12}$

\section{Penegakkan Hukum Lingkungan Merupakan Bagian Dari Siklus Pengaturan Lingkungan (regulatory chain)}

1. Penegakkan Hukum Lingkungan

Penegakkan hukum merupakan upaya yang dilakukan untuk menjadikan hukum sebagai pedoman perilaku dalam setiap perbuatan hukum baik oleh para subjek hukum yang bersangkutan maupun oleh aparatur penegakan hukum yang resmi diberi tugas dan kewenangan oleh undang-undang untuk menjamin berfungsinya norma-norma hukum yang berlaku dalam kehidupan bermasyarakat dan bernegara. ${ }^{13}$ Keberhasilan suatu peraturan perundang-undangan bergantung pada penerapan dan penegakannya. Penegakan hukum lingkungan dalam Undang-undang Nomor 32 Tahun 2009 bersifat preventif dan represif. Upaya preventif dalam rangka pengendalian dampak lingkungan hidup perlu dilaksanakan dengan mendayagunakan secara maksimal instrumen pengawasan dan perizinan yang dapat dilakukan oleh pemerintah, pemerintah daerah dan masyarakat. Sedangkan untuk upaya represifnya dilakukan apabila pencemaran dan perusakan lingkungan hidup yang sudah terjadi, baik melalui instrumen hukum administrasi, instrumen hukum perdata dan instrumen hukum pidana.

\footnotetext{
12 Jur Andi Hamzah, September 2005, Penegakkan hukum lingkungan, Sinar Grafika Jakarta, September, hal 40.

${ }^{13}$ Penegakkan Hukum Jimly Asshiddiqie http://www.jimly.com/makalah/namafile/56/Penegakan_Hukum.pdf. diakses 3 Feb.2020, pukul 22.20.
} 
Pendapat Bagir Manan mengatakan bahwa: keberhasilan suatu peraturan perundang-undangan bergantung pada penerapan dan penegakannya, apabila penegakan hukum tidak berjalan dengan baik, peraturan perundang-undangan bagaimanapun sempurnanya tidak atau kurang memberikan arti sesuai dengan tujuannya, penegakan hukum merupakan dinamisator peraturan perundang-undangan. ${ }^{14}$ Perhatian terhadap lingkungan hidup belakangan ini mendapat sorotan tajam, karena lingkungan hidup sudah semakin parah akibat dari pencemaran dan perusakan yang diakibatkan oleh ulah atau tingkah laku manusia itu sendiri. Pencemaran dan kerusakan lingkungan adalah pelanggaran hak orang lain yang telah dijamin oleh Undang-undang Dasar Republik Indonesia Tahun 1945 dan Undang-undang tentang perlindungan dan pengelolaan lingkungan hidup (UUPPLH), yaitu hak atas lingkungan yang baik dan sehat sebagai bagian dari hak asasi manusia. Pasal 28 H UUD 1945 tersebut, pada ayat (1) menetapkan bahwa setiap orang berhak hidup sejahtera lahir dan batin, bertempat tinggal dan mendapatkan lingkungan hidup yang baik dan sehat serta berhak memperoleh pelayanan kesehatan. Pasal 9 ayat (3) Undangundang No. 39 Tahun 1999 tentang Hak Asasi Manusia (HAM) menetapkan bahwa setiap orang berhak atas lingkungan hidup yang baik dan sehat.

Dengan dilanggarnya hak atas lingkungan yang baik dan sehat menjadi dasar bagi pihak yang dirugikan untuk mengajukan gugatan guna memperoleh ganti kerugian. Menurut Suparto Wijoyo, hak setiap orang atas lingkungan hidup yang baik dan sehat merupakan argumentasi hukum yang sangat substantif bagi seseorang untuk melakukan gugatan lingkungan terhadap pemenuhan kedua fungsi hak perseorangan termasuk melalui forum pengadilan.

Keith Hawkins mengemukakan bahwa penegakan hukum dapat dilihat dari dua sistem atau strategi yang disebut compliance dengan conciliatory style sebagai karakteristiknya dan sanctioning dengan penal style sebagai karakteristiknya. ${ }^{15}$ Secara lebih luas penegakan hukum lingkungan preventif mengarah pada pengawasan yang dilakukan oleh pihak yang berwenang. Dalam hal pengawasan terletak pada pejabat pemberi izin usaha dan atau kegiatan sesuai dengan kewenangannya. Pemerintah dan Pemerintah Daerah dapat menetapkan pejabat pengawas terhadap kegiatan yang dilakukan pada

\footnotetext{
${ }^{14}$ Solikin, Penegakan Hukum Lingkungan Menurut UU No. 32/2009, KANUN No. 52 Edisi Desember 2010 543, diakses 3 Februari 2020, pukul 23.05.

${ }^{15}$ ibid
} 
lingkungan hidup. Pada pasal 73 Undang-undang No. 32 Tahun 2009 menegaskan bahwa : Menteri dapat melakukan pengawasan terhadap ketaatan penanggung jawab usaha dan/atau kegiatan yang izin lingkungannya diterbitkan oleh pemerintah daerah jika pemerintah menganggap terjadi pelanggaran yang serius di bidang perlindungan dan pengelolaan lingkungan hidup. Pelanggaran yang serius itu yang diakibatkan oleh karena adanya tindakan yang melanggar hukum yang mengakibatkan pencemaran dan/atau kerusakan lingkungan hidup yang relatif besar dan menimbulkan keresahan di masyarakat. Ketika terjadi pelanggaran lingkungan secara serius dan butuh penanganan yang lebih, maka pemerintah memiliki kewenangan untuk melakukan tindakan hukum tertentu sehingga pencemaran dan/atau perusakan yang dilakukan penanggungjawab usaha dan/atau kegiatan tidak meluas dan dapat segera ditangani. Penegakkan hukum lingkungan hidup (law enforcemen; rechtshandhaving) lingkungan merupakan mata rantai terakhir dalam siklus pengaturan (regulatory chain). Perencanaan kebijakan (policy Planning) tentang lingkungan yang urutannya sebagai berikut : ${ }^{16}$

1) Perundang-undangan (legislation, wet en regelgeving).

2) Penentuan standar (standar setting, norm setting).

3) Pemberian izin (licensing, vergunning verlening).

4) Penerapan (implementation, uitvoering).

5) Penegakkan hukum (law enforcement, rechtshandhaving).

Gambar : siklus pengaturan (regulatory chain). ${ }^{17}$

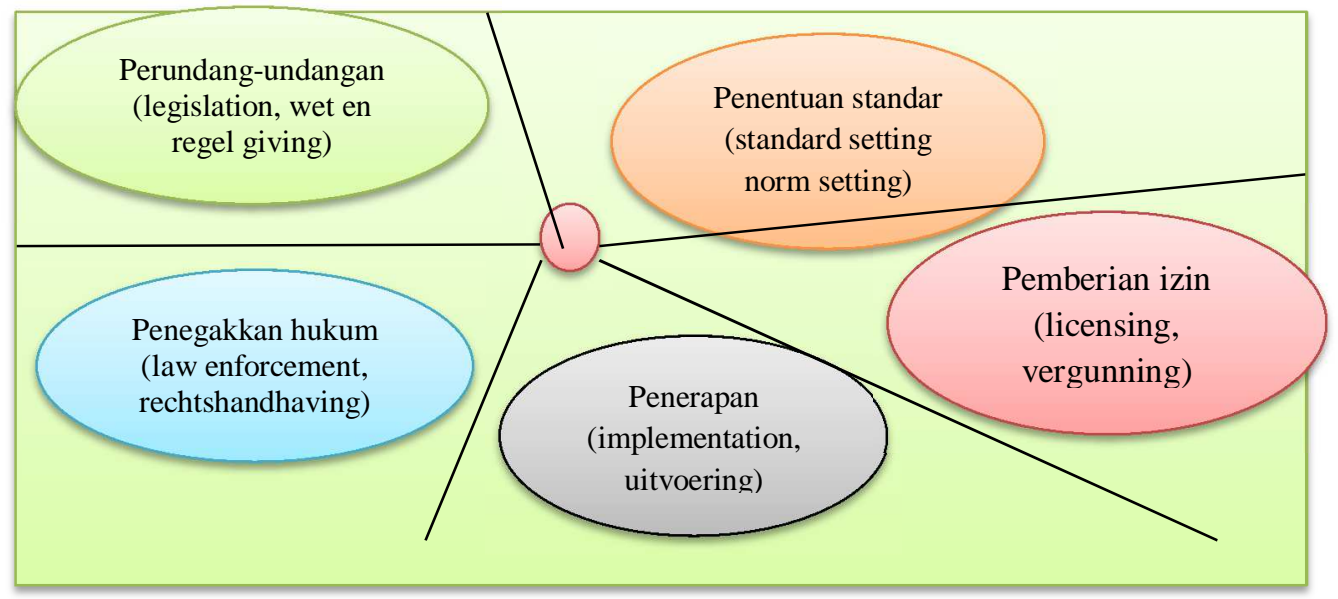

${ }^{16}$ Op.cit, hal 52

${ }^{17}$ Ibid, jur. Andi Hamzah, hal 56 
Oleh karena itu, pemerintah dan masyarakat harus serius untuk meningkatkan dan menggalakkan penegakkan hukum lingkungan termasuk yang preventif dan represif. Dengan demikian, diperlukan pendidikan dan latihan para penegak hukum termasuk pejabat administrasi bahkan masyarakat luas sadar lingkungan, kemudian melakukan usaha penegakkan hukum termasuk yang preventif (compliance) atau penataan hukum sebagai bagian peningkatan kesadaran hukum lingkungan.

\section{Proses Penegakkan Hukum Lingkungan}

Pada umumnya suatu masalah lingkungan hidup itu dimulai dari suatu titik yaitu terjadinya pelanggaran hukum lingkungan.Titik tersebut dimulai dari orang/pribadi, masyarakat, ataupun korban dari suatu pelanggaran hukum lingkungan. Tujuan tempat melapor terjadinya pelanggaran hukum lingkungan kepada kantor lingkungan hidup sehingga dapat diketahui apakah benar terjadi pencemaran atau perusakan lingkungan.

Dari kantor lingkungan hidup dapat dipilih proses selanjutnya, yaitu tentang ketentuan mana yang dilanggar apakah ketentuan adminsitrasi yakni tentang pelanggaran perizinan, atau pelanggaran tersebut bersifat perdata yakni perbuatan melanggar hukum yang terkait dengan pasal 1365 KUHPerdata yakni bahwa tiap perbuatan melanggar hukum yang membawa kerugian kepada seorang lain mewajibkan orang yang karena salahnya menerbitkan kerugian itu, mengganti kerugian tersebut. Terhadap pelanggaran lingkungan hidup yang sifatnya kriminal/ pelanggaran yang di maksud dalam kejahatan lingkungan hidup maka dilanjutkan keproses ranah hukum pidana.

Anggota masyarakat yang menjadi korban pencemaran atau kerusakan lingkungan hidup dapat mengajukan gugatan perdata ke Pengadilan atas nama kepentingan masyarakat. Jika masyarakat akan mengajukan ke jalur pengadilan pidana, maka dapat membuat laporan pidana ke kantor kepolisian. Siapapun yang mengetahui kejadian kejahatan lingkungan wajib melaporkan kepada polisi. Hukum pidana tidak berdiri sendiri sebagai instrument penegakkan hukum, tapi berkaitan pula dengan hukum administratif dan hukum perdata yang diterapkan oleh para penegak hukum. Konsep dasar penerapan hukum lingkungan tergantung kepada objek yang mana yang akan perlu mendapatkan perlindungan oleh hukum dan bagaimana hal itu diatur dengan peraturan. Karena penegakkan hukum itu dilakukan oleh aparat pemerintah sehingga ada ketergantungan dari penegak hukum 
kepada kebijakan pembangunan dan lingkungan pemerintah. ${ }^{18}$ Bahwa perbedaan antara sanksi admnistrasi dan sanksi pidana serta sanksi perdata adalah yang pertama menghendaki pemulihan atau perbaikan kembai kepada keadaan semula, sedangkan yang kedua adalah pengenaan nestapa yang istimewa yakni sanksi pidana dan yang ketiga mengenai ganti rugi.

Hal yang perlu diperhatikan bahwa dari semua jalur baik itu melalui sanksi hukum administrasi, sanksi hukum perdata dan sanksi hukum pidana, memerlukan keterang saksi dan atau keterang ahli di bidang lingkungan hidup. Perlu diperhatikan pula, karena hukum lingkungan menempati posisi beberapa bidang hukum, objek dan pengaturannya menempati beberapa sektor maka penanganan pelanggarannya tidak dapat dilepaskan dari kebijakan lingkungan dari pemerintah.

\section{PEMBAHASAN}

\section{A. Pembangunan yang Berkelanjutan sebagai Dasar dan Terintegrasi di dalam Pembangunan suatu Wilayah}

Pembangunan selalu membawa perubahan dan dampak positif maupun negatif. Dampak positif merupakan salah satu tujuan dari dilaksanakannya pembangunan yaitu perubahan positif bagi manusia dalam mencapai kesejahteraannya. ${ }^{19}$ Konsep daripada pembangunan berkelanjutan harus mempertimbangkan aspek negatifnya terhadap lingkungan baik aspek hayati (ekosistem) dan non hayati (sosial budaya).

Pembangunan yang berkelanjutan (sustainable development) adalah upaya sadar dan terencana yang memadukan aspek lingkungan hidup, social dan ekonomi kedalam strategi pembangunan untuk menjamin keutuhan lingkungan hidup serta keselamatan, kemampuan, kesejahteraan dan mutu hidup generasi masa kini dan genarasi masa depan. Prinsip-prinsip yang terkandung dalam konsep pembangunan berkelanjutan dikemukakan secara rinci dalam deklarasi dan perjanjian Internasioanl yang dihasilkan melalui konferensi PBB tentang lingkungan dan pembangunan (United Nation Conference on Environment and Development) di Rio de Jeneiro pada Tahun 1992. Dari berbagai dokumen yang dihasilkan dari konferensi itu secara formal terdapat lima prinsip utama pembangunan berkelanjutan yaitu : ${ }^{20}$

1. Prinsip keadilan antargenerasi (Intergenerational equity Principle).

\footnotetext{
${ }^{18}$ Ibid., hal 60.

${ }^{19}$ Marhaeni Ria Siombo, Op Cit, hal 58.

${ }^{20}$ Ibid, hal 61-62.
} 
Prinsip ini mengandung makna bahwa setiap generasi umat manusia di dunia memiliki hak untuk menerima dan menempati bumi bukan dalam kondisi yang buruk akibat perbuatan generasi sebelumnya.

2. Prinsip keadilan dalam satu generasi (Intergenerational Equity Principle). Prinsip ini merupakan prinsip yang berbicara tentang keadilan di dalam sebuah generasi umat manusia, dimana beban dari permasalahan lingkungan harus dipikul bersama oleh masyarakat dalam satu generasi.

3. Prinsip pencegahan dini (precautionary principle). Prinsip ini mengandung pengertian bahwa apabila ada ancaman yang berat atau ancaman kerusakan lingkungan yang tidak dapat di pulihkan serta ketiadaan temuan atau pembuktian ilmiah yang konsklusif dan pasti tidak dapat dijadikan alasan untuk menunda upaya-upaya untuk mencegah terjadinya kerusakan lingkungan.

4. Prinsip perlindungan keragaman hayati. Prinsip ini merupakan prasyarat dari berhasil tidaknya pelaksanaan prinsip keadilan antar generasi. Perlindungan keragaman hayati diperlukan demi pencegahan dini.

5. Prinsip internalisasi biaya lingkungan. Kerusakan lingkungan dapat dilihat sebagai external cost dari suatu kegiatan ekonomi yang diderita oleh pihak yang tidak terlibat dalam kegiatan ekonomi tersebut. Jadi kerusakan lingkungan merupakan external cost yang harus ditanggung oleh pelaku ekonomi. Oleh karena itu, biaya kerusakan lingkungan harus diintegrasikan kedalam proses pengambilan keputusan yang berkaitan dengan penggunaan sumber-sumber alam tersebut.

Pembangunan dan pelestarian lingkungan merupakan kepentingan yang sama-sama penting. Melihat kuatnya interaksi dan ketergantungan antara kedua faktor itu maka diperlukan pendekatan konsep pembangunan berkelanjutan dan pembangunan yang berwawasan lingkungan (sustainable development), konsep yang mengintegrasikan kepentingan ekonomi, sosial, budaya dan aspek pelestarian lingkungan. Agar prinsip pembangunan berkelanjutan di Indonesia bisa dilaksanakan sebagaimana mestinya, reformasi regulasi di bidang lingkungan hidup mengalami penyempurnaan seiring dengan berkembangnya kebutuhan manusia akan lingkungan hidup yang sehat. Maka Undang-undang No.4 Tahun 1982 tentang Lingkungan Hidup disempurnakan dengan Undang-undang No.23 Tahun 1997 tentang Pengelolaan Lingkungan Hidup dan terakhir disempurnakan lagi dengan Undang-undang No. 32 Tahun 2009 tentang Perlindungan Dan Pengelolaan Lingkungan Hidup. ${ }^{21}$ Dengan tujuan untuk mengontrol dan mengawasi pelaksanaan pembangunan agar sesuai dengan

${ }^{21}$ Ibid, hal 69 
prinsip sustainable development, yang mana perencanaan pembangunan yang direncanakan di rencanakan di lingkungan hidup mewajibkan disusunnya dokumen tentang analisis mengenai dampak lingkungan (amdal).

Analisis mengenai dampak lingkungan hidup perlu dilakukan untuk menjaga keseimbangan suatu ekosistem, disamping untuk melakukan rangkaian upaya pengelolaan sehingga bisa secepatnya dilakukan pembaharuan apabila terjadi penurunan kualitas lingkungan hidup karena terjadinya gangguan keseimbangan ekosistem. Dengan adanya kajian terhadap suatu kegiatan atau pembangunan yang direncanakan pada lingkungan menjadi bagian penting dalam pengambilan keputusan terhadap layak atau tidak layaknya dari suatu kegiatan pembangunan. Oleh karena pelaksanaan telaahan atau kajian mengenai dampak lingkungan tersebut, harus dilaksanakan secara konsisten, karena merupakan upaya untuk mengawasi dan mengontrol pelaksanaan kegiatan yang dilakukan oleh pemangku kepentingan dengan harapan prinsip pembangunan yang berwawasan lingkungan dapat berjalan dengan optimal dan studi amdal akan meminimalkan dampak negatif yang terjadi.

Pengelolaan lingkungan hidup harus secara optimal dicanangkan serta diupayakan pada pembangunan berwawasan lingkungan hidup dan pembangunan berkelanjutan dengan tujuan untuk kesejahteraan masyarakat dan juga memikirkan untuk kepentingan generasi selanjutnya. Yaitu melihat secara menyeluruh segala aspek sosial, budaya, keamanan dan berkelanjutan sumber daya. Manusia dan alam sekitarnya, makhluk hidup dan tak hidup merupakan satu kesatuan yang saling berinteraksi di dalam lingkungan hidup sebagaimana disebutkan pada pasal langka 1 Undang-Undang No.32 Tahun 2009 bahwa lingkungan hidup adalah kesatuan ruang dengan semua benda, daya, keadaan dan makhluk hidup termasuk manusia dan perilakunya yang mempengaruhi alam itu sendiri, kelangsungan perikehidupan dan kesejahteraan manusia serta makhluk hidup lain. Sehingga sangat perlu untuk dikelola dengan melihat dan mempertimbangkan unsur-unsur tersebut, adalah merupakan bagian dari ekosistem yang saling melengkapi dan saling berinteraksi. Ekosistem merupakan suatu rangkaian komponen-komponen yang membentuk satuan-satuan fungsional. Kehidupan berlangsung dalam berbagai fenomena kehidupan menurut prinsip, tatanan, hukum alam atau ekologi, seperti keseimbangan (homeostatis), kelentingan (resilience), kompetisi, toleransi, adaptasi, suksesi, evolusi dan mutasi. 


\section{B. Penegakkan Hukum Lingkungan terhadap Kegiatan Pembangunan}

Setiap kegiatan pembangunan yang dilakukan manusia pada lingkungan hidup pada dasarnya selalu menimbulkan perubahan pada alam lingkungannya, artinya tiada kegiatan pembangunan tanpa risiko pengubahan lingkungan hidup. Karena itu setiap kegiatan pembangunan sebelum di mulai aktifitasnya terlebih dahulu dilakukan suatu kajian mengenai analisis dampak lingkungan untuk menentukan bahwa pembangunan yang dilaksanakan pada lingkungan hidup itu banyak membawa manfaat atau kesejahteraan pada masyarakat khususnya masyarakat sekitar ataukah malah akan membawa kesengsaraan. Oleh karena itu, perlu diatur secara hukum agar setiap kegiatan pembangunan pada lingkungan hidup dapat dipertanggung jawabkan apabila terjadi akibat yang fatal dikemudian hari, terutama penanganan pada dampak negatif yang ditimbulkan akibat kegiatan pembangunan tersebut.

Pasal 33 Ayat (3) Undang-undang Dasar Negara Republik Indonesia Tahun 1945 sebagai landasan konstitusional mengamanatkan bahwa bumi, air dan kekayaan alam yang terkandung di dalamnya dikuasai oleh negara dan dipergunakan untuk sebesar-besarnya kemakmuran rakyat. Ruang wilayah Negara Kesatuan Republik Indonesia yang merupakan negara kepulauan berciri Nusantara baik sebagai kesatuan wadah yang meliputi ruang darat, ruang laut, dan ruang udara, termasuk di dalam bumi, maupun sebagai sumber daya, perlu ditingkatkan upaya pengelolaannya secara bijaksana, berdaya guna dan berhasil guna dan dikelola secara berkelanjutan untuk sebesar-besarnya kemakmuran rakyat. Mengingat sumber ekonomi dan kekayaan alam di negeri ini tidak lagi menjadi monopoli semata, melainkan berasaskan kebersamaan dan kemerataan secara adil dan berkelanjutan.

Penataan ruang diyakini sebagai pendekatan yang tepat dalam mewujudkan keterpaduan pengelolaan sumber daya alam dan sumber daya buatan secara berdaya guna dan berhasil guna. Diharapkan pada kaidah kaidah penataan ruang, kualitas ruang wilayah nasional dapat terjaga keberlanjutannya demi terwujudnya kesejahteraan umum dan keadilan sosial sesuai dengan landasan konstitusional UUD Tahun 1945.

Penyelenggaraan tata ruang di Indonesia telah diatur dengan Undang-Undang Nomor 26 Tahun 2007 tentang Penataan Ruang (UUPR). UUPR mengatur bahwa masing-masing daerah harus menetapkan Rencana Tata Ruang Wilayah (RTRW) Provinsi maupuan kabupaten/kota. Penetapan RTRW untuk suatu pembangunan, itu sangat terkait dan juga berpengaruh pada masalah perlindungan dan pelestarian lingkungan hidup. Oleh karena itu, kegiatan suatu pembangunan harus berprinsip pada pembangunan yang berkelanjutan yang berwawasan lingkungan dan 
menjadi dasar terintegrasi dalam pembangunan suatu wilayah, sebagaimana diatur dalam Undang-Undang No. 32 Tahun 2009 tentang 'Perlindungan dan Pengelolaan Lingkungan Hidup', sehingga memacu pada setiap pelaksanaan pembangunan dengan konsep berwawasan lingkungan yang lebih terbuka dan responsif terhadap kepentingan masyarakat luas. Penyelenggaraan penataan ruang yang komprehensif, holistik, terkoordinasi, terpadu, efektif dan efisien dengan memperhatikan faktor politik, ekonomi, sosial, budaya, pertahanan, keamanan, dan kelestarian lingkungan hidup. Dengan adanya penataan ruang wilayah lingkungan hidup dapat mengharmoniskan lingkungan alam dan lingkungan buatan serta keterpaduan penggunaannya dan memberikan perlindungan terhadap fungsi ruang dan pencegahan dampak negatif terhadap lingkungan hidup akibat pemanfaatan ruang dari pelaksanaan pembangunan. Ruang adalah wadah yang meliputi ruang darat, ruang laut, dan ruang udara, termasuk ruang di dalam bumi sebagai satu kesatuan wilayah, tempat manusia dan makhluk hidup lainnya dalam melakukan kegiatan dan memelihara kelangsungan kehidupannya.

Siti Sundari Rangkuti menyatakan substansi dari Undang-undang tentang pengelolaan lingkungan harus memuat prinsip-prinsip kebijaksanaan lingkungan (principles of environmental policy) untuk dituangkan dalam aturan yang berisi norma hukum sebagai berikut: ${ }^{22}$

1. Abatement at the sorce (penanggulangan pada sumbernya).

2. The best available Technology $(B A T)=$ the"alara principle" ("as low as reasonably achieveable").

3. The polluter pays principle (prinsip pencemar membayar).

4. Stand still principle (prinsip cegat tangkal/cekal).

5. Principle of regional differentiation (prinsip perbedaan regional).

6. Shifting the burden of proof ="hetbeginsel van de omkering der bewijslast"(beban pembuktian terbalik).

Undang-undang No. 32 Tahun 2009 adalah peraturan hukum lingkungan hidup yang mendayagunakan berbagai ketentuan hukum yaitu hukum administrasi, hukum perdata dan hukum pidana. Ketentuan hukum perdata meliputi penyelesaian sengketa lingkungan hidup di luar pengadilan dan di dalam pengadilan. Penyelesaian sengketa lingkungan hidup di dalam pengadilan meliputi gugatan perwakilan kelompok, hak gugat organisasi lingkungan ataupun hak gugat pemerintah. Melalui gugatan tersebut, diharapkan akan meningkatkan kesadaran seluruh pemangku kepentingan tentang betapa pentingnya perlindungan dan pengelolaan lingkungan hidup. Penegakkan hukum pidana pada Undang-

\footnotetext{
${ }^{22}$ Penegakan Hukum Lingkungan: (Franky Butar Butar) Yuridika Vol. 25 No. 2, Mei-Agustus 2010: 151-168, diakses Jumat 6 Des 2019 pukul 19.29.1
} 
undang No.32 Tahun 2009 itu mengatur ancaman hukuman minimum disamping maksimum, perluasan alat bukti, pemidanaan bagi pelanggaran baku mutu lingkungan, keterpaduan penegakkan hukum pidana dan pengaturan tindak pidana koorporasi. Penegakkan hukum pidana lingkungan tetap memperhatikan asas ultimum remedium yang mewajibkan penerapan penegakkan hukum pidana sebagai upaya terakhir setelah penerapan penegakkan hukum adminsitrasi dianggap tidak berhasil. Penerapan asas ultimum remedium hanya berlaku bagi tindak pidana formil tertentu yaitu pemidanaan terhadap pelanggaran baku mutu air limbah, emisi dan gangguan. Penegakkan hukum pidana terhadap pelaku tindak pidana lingkungan hidup dapat dilakukan penegakkan hukum terpadu antara penyidik pegawai negeri sipil, kepolisian, dan kejaksaan di bawah koordinasi menteri. Tindak pidana dalam Undangundang No. 32 Tahun 2009 merupakan kejahatan. Pada pasal 97 Undangundang tentang perlindungan dan pengelolaan lingkungan hidup menyatakan bahwa jika setiap orang dengan sengaja melakukan perbuatan yang mengakibatkan dilampauinya baku mutu udara ambien, baku mutu air, baku mutu air laut atau kriteria baku kerusakan lingkungan hidup dipidana dengan pidana penjara paling singkat 3 (tiga) tahun dan paling lama 10 (sepuluh ) tahun dan denda paling sedikit Rp.3.000.000.000,-(tiga miliar rupiah) dan paling banyak Rp.10.000.000.000,- (sepuluh miliar rupiah). Pada sanksi administratif Menteri, Gubernur, Bupati/Walikota menerapkan sanksi adminsitrasi kepada penanggung jawab usaha dan/atau kegiatan jika dalam pengawasan ditemukan pelanggaran terhadap izin lingkungan. Sanksi administrasi pada pasal 76 ayat 2 Undang-undang tentang perlindungan dan pengelolaan lingkungan hidup, terdiri dari teguran tertulis, paksaan pemerintah, pembekuan izin lingkungan atau pencabutan izin lingkungan.

Akan tetapi, bagaimana jika sesudah pengenaan sanksi administrasi dituntut lagi menurut hukum pidana atau sebaliknya atau juga dengan sanksi (gugatan) perdata. Bahwa tujuan hukum pidana yang berbeda dengan hukum administrasi dan hukum perdata, maka jawabannya adalah bahwa hukum pidana terutama menjatuhkan sanksi kepada sobjek hukumnya yang melanggar ketentuan pidananya yang telah diatur dalam Undang-Undang lingkungan tersebut, yang mana dalam sanksi pidana selain penjara atau kurungan juga ada hukuman denda, sedangkan pada sanksi administatif dan sanski perdata menekankan pada pencabutan izin, pemulihan keadaan dan ganti kerugian. Penerapan hukum pidana atau terhadap pelanggaran hukum lingkungan banyak tergantung juga pada hukum adminsitratif atau hukum pemerintahan, terutama yang menyangkut perizinan. Inilah yang disebut oleh Faure sebagai 
ketergantungan administratif hukum pidana lingkungan (de administratieve afhankelijkheid van het millieu strafrecht).

Tujuan negara yang tercantum pada alinea keempat UUD 1945 bahwa Negara Indonesia termasuk negara hukum kesejahteraan. Tujuan Negara tersebut, dilaksanakan salah satunya adalah di bidang lingkungan hidup yang dituangkan dalam peraturan perundang- undangan dan dalam rangka perlindungan dan pengelolaan lingkungan hidup di Indonesia maka salah satu otoritas pemerintah yaitu menerapkan izin lingkungan (environmental licence) pada setiap kegiatan dan/atau pembangunan yang dijalankan di lingkungan hidup. Agar lebih menjamin kepastian hukum dan memberikan perlindungan terhadap hak setiap orang untuk mendapatkan lingkungan hidup yang baik dan sehat sebagai bagian dari perlindungan terhadap keseluruhan ekosistem. Bahwa lingkungan hidup yang baik dan sehat itu merupakan hak asasi setiap warga Negara Indonesia sebagaimana diamanatkan dalam pasal $28 \mathrm{H}$ Undang-undang Dasar Negera Republik Indonesia Tahun 1945.

Oleh karena itu, pelaksanaan telaahan atau kajian mengenai dampak lingkungan tersebut, harus dilaksanakan secara konsisten karena merupakan upaya untuk mengawasi dan mengontrol pelaksanaan kegiatan yang dilakukan oleh pemangku kepentingan dengan harapan prinsip pembangunan yang berwawasan lingkungan dapat berjalan dengan optimal dan studi amdal akan meminimalkan dampak negatifnya.

Perlindungan dan pengelolaan lingkungan hidup merupakan upaya sistematis dan terpadu yang dilakukan untuk melestarikan fungsi lingkungan hidup dan mencegah terjadinya pencemaran dan/atau kerusakan lingkungan hidup yang meliputi perencanaan, pemanfaatan, pengendalian, pemeliharaan, pengawasan dan penegakkan hukum lingkungan. Oleh karena itu, lingkungan hidup Indonesia harus dilindungi dan dikelola dengan baik berdasarkan rasa tanggung jawab, berkelanjutan dan berkeadilan serta dapat memberikan kemanfaatan ekonomi, sosial dan budaya yang dilakukan berdasarkan prinsip kehati-hatian, demokrasi lingkungan, desentralisasi dan juga pengakuan dan penghargaan terhadap kearifan lokal dan kearifan lingkungan.

Penggunaan sumber daya alam dilakukan secara terencana, rasional, optimal, bertanggung jawab dan sesuai dengan kemampuan daya dukungnya dengan mengutamakan sebesar-besarnya kemakmuran rakyat, memperkuat struktur ekonomi yang memberikan efek pengganda yang maksimum terhadap pengembangan dan atau pembangunan dengan tetap memperhatikan kelestarian fungsi dan keseimbangan lingkungan hidup. Maka perlu dikembangkan sistem hukum perlindungan dan pengelolaan lingkungan hidup yang jelas, tegas dan menyeluruh guna menjamin kepastian hukum sebagai landasan bagi perlindungan dan pengelolaan 
sumber daya alam serta kegiatan dengan perubahan lingkungan. Undangundang No. 32 Tahun 2009 mendayagunakan berbagai ketentuan hukum, baik ketentuan hukum administrasi, hukum perdata maupun hukum pidana. Dan juga berlandaskan pada rencana tata ruang wilayah dalam pembangunan yang mencakup pemanfaatan sumber daya alam yang berkelanjutan dan pelestarian lingkungan hidup dengan memperhatikan daya dukung dan daya tampung lingkungan untuk menjaga ekosistem yang ada serta dilakukan secara produktif, efektif, efisien, tertib, aman dan adil.

\section{A. Kesimpulan}

\section{PENUTUP}

1. Peraturan perundang-undangan sebagai dasar pelaksanaan pembangunan yang berwawasan lingkungan hidup yaitu Undangundang No. 32 Tahun 2009 tentang 'Perlindungan dan Pengelolaan Lingkungan Hidup', merupakan peraturan yang sudah komprehensif dan responsive dalam memacu pelaksanaan pembangunan yang berwawasan lingkungan hidup dan menjadi dasar terintegrasi dalam pembangunan suatu wilayah serta lebih terbuka dan memperhatikan terhadap kepentingan rakyat yang membawa perubahan pelaksanaan pmbangunan dengan konsep pembangunan yang berkelanjutan (sustainable development)

2. Analisis mengenai dampak lingkungan hidup perlu dilakukan untuk menjaga keseimbangan suatu ekosistem, disamping untuk melakukan rangkaian upaya pengelolaan sehingga bisa secepatnya dilakukan pembaharuan apabila terjadi penurunan kualitas lingkungan hidup karena terjadinya gangguan keseimbangan ekosistem.

3. Pengenaan sanksi merupakan salah satu upaya pengendalian pemanfaatan lingkungan hidup, dimaksudkan sebagai perangkat tindakan penertiban atas pemanfaatan lingkungan hidup yang tidak sesuai dengan rencana atau ketentuan yang ada. Pemanfaatan lingkungan hidup dan atau sumber daya alam yang tidak sesuai dengan rencana, baik yang dilengkapi dengan izin maupun yang tidak memiliki izin, dikenai sanksi hukum administratif misalkan pencabutan izin, pemulihan lingkungan hidup dan sanksi hukum pidana serta sanksi hukum perdata.

4. Dengan demikian penegakkan hukum lingkungan bertujuan untuk memperbaiki perilaku manusia atas lingkungan hidup dengan memberi sanki kepada pembuat (pelanggar hukum lingkungan) agar dapat berubah dan memperhatikan lingkungan hidup serta hak orang lain untuk hidup di dalam lingkungan yang sehat dan tenteram. 


\section{B. Saran}

1. Para pengambil keputusan dan penentu kebijakan pemerintah wajib menjabarkan Undang-Undang tentang perlindungan dan pengelolaan lingungan hidup ke dalam kebijakan teknis di masing-masing sektor. Dan pemberian sanksi yang tegas sesuai hukum yang berlaku.

2. Sudah saatnya bangsa Indonesia tidak hanya melulu mengeksploitasi kekayaan alam secara besar-besaran, tetapi juga harus bersungguhsungguh memulihkan dan menjaga kelestarian dan kelangsungan lingkungan hidupnya demi kepentingan Negara, bangsa, masyarakat dan generasi yang akan datang. Pemerintah harus serius untuk menegakkan hukum lingkungan secara tegas dan adil. Para penegak hukum juga harus memiliki kemampuan tentang lingkungan hidup oleh karenanya di perlukan pula untuk mengikuti pelatihan dan/ atau pendidikan tentang lingkungan hidup, sehingga jika ada sengketa tentang lingkungan hidup dapat di selesaikan dengan baik.

\section{DAFTAR PUSTAKA}

\section{Buku Bacaan}

Amos Neolaka, 2008, Kesadaran Lingkungan, Rineke Cipta, Jakarta.

Achmad Ali dan Wiwie Heryani, 2012, Resep Hukum., Sebuah Bunga Rampai, Kencana, Prenada Media Group.

A'an Efendi, 2012, Penyelesaian sengketa lingkungan, Mandar Maju.

Jur Andi Hamzah, September 2005, Penegakkan hukum lingkungan, Sinar Graffika Offset.

Gatot Susanta., Hari Sutjahjo., Cetakan ke III 2008, Pemanasan Global, Penebar Swadaya.

Joko Subagyo, Desember 2005 Hukum Lingkungan dan Masalah Penanggulangannya, PT. Rineka Cipta, Jakarta.

Koesnadi Hardjasoemantri., 2009, Hukum Tata Lingkungan, edisi VIII, Gadjah Mada University Press.

Marhaeni Ria Siombo, 2012, Hukum Lingkungan \& Pelaksanaan Pembangunan Berkelanjutan di Indonesia. Gramedia Pustaka Utama, Jakarta.

Muhamad Erwin., 2011, Hukum Lingkungan dalam sistem kebijakan pembangunan lingkungan hidup, Refika Aditama. 
Mohamad Soerjani, Pendidikan Lingkungan (Environmental Education), sebagai dasar sikap dan perilaku bagi kelangsungan kehidupan menuju pembangunan berkelanjutan, hak cipta, Yayasan Institut Pendidikan dan Pengembangan Lingkungan IPPI., Jakarta

\section{Peraturan Perundang-undangan.}

Undang-Undang Dasar 1945.

Undang-Undang Nomor 32 Tahun 2009 tentang Perlindungan dan Pengelolaan lingkungan Hidup.

\section{Sumber Lain}

https://www.cnbcindonesia.com/news/20190429142653-4-

69429/reklamasi-pascatambang-jonan-tak-ada-ampun-untukpelanggar.

Penegakan Hukum Lingkungan: (Franky Butar Butar) Yuridika Vol. 25 No. 2, Mei-Agustus 2010: 151-168 